\section{Berkeley puts $\$ 500 \mathrm{~m}$ into multidisciplinary approach to disease}

\section{San Diego}

The University of California at Berkeley last week announced a $\$ 500$ million Health Sciences Initiative, which will bring together biologists, physicists, mathematicians and computer scientists to address human disease.

About $\$ 300$ million will be used to construct new laboratory buildings and $\$ 200$ million will be spent on researchers and new equipment.

Berkeley, which lacks a medical school is seeking to create an interdisciplinary initiative that produces both biological discoveries and human products, from artificial tissues to drugs.

Robert Tjian, a professor of molecular and cell biology, Howard Hughes Medical Institute researcher and co-leader of the initiative, says that many future breakthroughs in biology will occur "at the convergence of these diverse fields".

Thomas Budinger, chair of the new bioengineering department - a combined effort involving the Berkeley campus and the University of California at San Francisco - says it will "bring engineering to biology and biologists to the methods and resources of engineering".

A Whitaker Foundation grant is expected to fund an expansion in bioengineering students, say Berkeley officials. The initiative also includes the new Helen Wills Neuroscience Institute, named after the former tennis star, whose estate donated $\$ 10$ million. Rex Dalton

\title{
Joint institute set to boost Austria's genome research
}

\section{Munich}

The Austrian Academy of Sciences and the pharmaceutical company Boehringer Ingelheim have announced plans to set up a high-profile Institute of Molecular and Cellular Bioinformatics (IMBA) in Vienna.

The new institute will work closely with Boehringer Ingelheim's Institute of Molecular Pathology (IMP) in Vienna, sharing its scientific advisory board and service facilities. The two institutes will form a new Genome Research Centre aimed at combining research in molecular biology and its potential medical applications.

The IMBA will be owned and financed by the Austrian Academy of Sciences, with money from the Austrian ministry for science and transport, and the city of Vienna will pay for the construction of a new building. Annual core funding will be about 100 million schillings (US $\$ 8$ million) a year.

Boehringer Ingelheim will have no direct control over the IMBA's research strategy, but will give it access to the IMP's scientific infrastructure, including sequencing facilities and electron microscopes.

All income from joint scientific research will be shared between the institutes in accordance with their input. Boehringer Ingelheim will have an option to buy the IMBA's share of an invention, or to license it.

The IMBA will house $60-80$ scientists in a new building adjacent to the IMP. The first groups will start work in temporary accommodation within a year, and recruitment of scientific staff will start immediately.
Kim Nasmyth, the IMP's scientific director, will keep his position at the IMP, but will also be responsible for establishing the IMBA's scientific programmes during the recruitment phase, and for coordinating the direction of research at the two institutes.

$\mathrm{He}$ is keen to create innovative career structures at the IMBA, which, like the IMP, will have no tenured positions. There will therefore be "huge and continuous opportunities for young scientists", says Nasmyth.

Research at the IMBA will focus on human molecular and cellular biology and, in particular, on the medical implications of research results from the IMP, which has been successful in basic research on model organisms aimed at understanding the origins of diseases such as cancer.

Research at the IMBA may include the development of methods for analysing normal and diseased human tissue, and identifying human polymorphisms that contribute to multigene diseases. Its bioinformaticists will work on transforming raw sequence data into knowledge for medical use.

Bernd Wetzel, head of international research and development at Boehringer Ingelheim, welcomes the decision by the Austrian Academy of Sciences to collaborate so closely with a privately funded institute. "They have recognized the mood of the times," he says.

Werner Welzig, president of the academy, says the cooperation with Boehringer Ingelheim marks a "new departure" for biological science in Austria.

Quirin Schiermeier

\section{Institut Pasteur names Kourilsky as new director}

\section{Paris}

France's leading medical research institute, the Institut Pasteur, last week named Philippe Kourilsky as its new director. Kourilsky, a specialist in molecular immunology who has been with the institute for 27 years, will replace Maxine Schwartz, whose second six-year term ends in January.

Under Schwartz, the institute's budget increased significantly to FF998 million (US\$160 million) in 1998, and it became heavily involved in fields such as the origins and treatment of AIDS.

Scientists at the Pasteur say Kourilsky's largest challenge will be to maintain its prestige as a competitive institution, while staying true to its nineteenth-century mission as a research institution focusing on

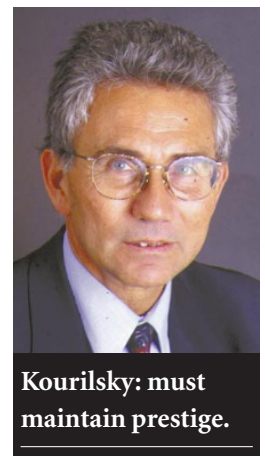

infectious diseases and public health.

"His major mandate is to make sure that Pasteur remains a prima donna in microbiological research," says Simon Wain-Hobson, director of a molecular retrovirology laboratory the institute. "We have to modernize and at the same time maintain our history."

Pasteur researchers say that Kourilsky is well placed to do this. He has been associated with the institute since 1972, but has also held posts at INSERM, France's national biomedical research agency, and in industry, at the Lyons-based company Laboratoires Mérieux. He is currently a professor of molecular immunology at the Collège de France and a research director at the Pasteur.

Kourislky is "both an insider - a true 'pasteurien' - and an outsider", says JeanLouis Virelizier, director of a viral immunology lab at the institute. "He has all the potential to be a good director," says Wain-Hobson. "I think he is politically savvy, bright, dynamic. The real test will be when he gets to work."

Major tasks facing the director, in addition to coordinating Pasteur's 22 institutions scattered throughout the world, include defining its research strategy in areas such as genomics. Heather McGabe 